\title{
Grønland - oprindeligt folk og moderne nation
}

\section{Grønland som dansk koloni}

For øjeblikket udspiller der sig en spektakulær debat i de grønlandske medier. Den er afstedkommet af den danske historiker og lektor ved Grønlands Universitet, Ilisimatusarfik, dr. phil. Thorkild Kjærgaard, som har formastet sig til at indtage det synspunkt, at Grønland ikke var en dansk koloni. Det har fået blandt andre forfatteren Kim Leine til at fare i blækhuset for at forsvare det synspunkt, at Grønland reelt var en dansk koloni, og at Danmark ved adskillige lejligheder agerede som regulær kolonimagt. I stedet, anfører Kjærgaard, har forholdet mellem Grønland og Danmark op igennem perioden 1721 (det år Hans Egede gik i land på Grønland) og 1953, året hvor Grønland blev et dansk amt, haft karakter af et forhold mellem ligestillede - et broderskab. Dette er ikke at ligne med den asymmetri, mange debattører har indlæst i den grønlandsk-danske relation, og som har givet anledning til blandt andet nedsættelsen af en forsoningskommission efter sydafrikansk forbillede af den nu forhenværende landstyreformand Aleqa Hammond fra det socialdemokratiske parti Siumut i 2014.

Til grund for denne debat ligger først og fremmest en begrebsmæssig diskussion om, hvad det vil sige at være koloni og kolonimagt. Det er en diskussion, som inviterer til indlæg fra både jurister, historikere og sidst men ikke mindst eskimologer. Synspunkterne er mange og meningerne delte. Inden for rammerne af dette særnummer er det tilstrækkeligt at holde sig for øje, at særligt i de seneste år har en debat om forholdet mellem Grønland og Danmark fundet sted, hvor kolonitiden spiller en afgørende rolle. Debatten finder typisk sted inden for Rigsfællesskabets relativt snævre rammer. Gør man sig imidlertid den ulejlighed at hæve blikket ud over Rigsfællesskabets grænser og inddrage de erfaringer, andre lande har gjort sig, konstaterer man gerne, at det grønlandsk-danske forhold ikke uden videre lader sig sammenligne med for eksempel de erfaringer, mange lande på det afrikanske kontinent og deres respektive kolonimagter har gjort sig. Om kontrasten til andre kolonier og kolonimagter er så stor, at begreberne koloni og kolonimagt ikke kan anvendes direkte på det grønlandsk-danske forhold, tilkommer det ikke forfatterne og redaktørerne af dette særnummer at afgøre. Vi vælger i stedet at følge debatten med spænding og bidrage til forståelsen af forholdet mellem Grønland og Danmark ved at kaste lys på udvalgte områder og problemstillinger, som ligger inden for den periode, som fulgte efter kolonitiden, nemlig perioden fra 1953, da Grønland med grundloven samme år fik status af dansk amt. Disse forhold er blevet belyst af forskere, som har arbejdet indgående med 
Grønlandsk mentalitetshistorie, men de har ikke hidtil været genstand for et sociologisk blik. Det er forfatternes og redaktørernes forhåbning at råde bod på denne udeladelse.

\section{Grønland som dansk amt}

Grønlands overgang til dansk amt bliver startskuddet til en lang række tiltag, som under ét kan betegnes som en af de mere drastiske moderniseringsprocesser, man har set i nyere tid. Fra dansk side var målsætningen, at grønlænderne skulle have adgang til de samme velfærdsgoder og -ydelser og dermed blive borgere i den samme type velfærdssamfund som resten af indbyggerne i Rigsfællesskabet og i særdeleshed Danmark. Det indvarslede en række meget vidtgående politikker og tiltag på blandt andet uddannelsesområdet, sundhedsområdet og boligområdet, som hævede standarderne for både sundhed og boligforhold ganske betragteligt. Det er vigtigt at understrege, at denne udvikling ikke er et isoleret grønlandsk fænomen. Man kan hævde, at Danmark undergik samme forandring blot ikke i samme voldsomme grad. Men tendenserne var de samme: ændrede standsforhold, andre kønsroller og nye opfattelser af status og magt - alt sammen faktorer som har været gjort til genstand for sociologisk forskning i Danmark. Tilsvarende interesse har danske sociologer ikke vist Grønland. Det kan undre, når man betænker, at for menneskene, som var omdrejningspunktet for denne forcerede moderniseringsproces, blev det en til tider meget voldsom overgang fra fanger- og fiskerkultur til en moderne tilværelse typisk i Grønlands største by, hovedstaden Nuuk. Det er denne udvikling, som ligger til grund for artiklerne, der udgør dette særnummer, og som gennemsyrer både Annemette Nyborg Lauritsens studie af afstraffelse og indespærring - eller snarere fraværet af afstraffelse og indespærring - i Grønland og Bo Wagner Sørensens og Søren Forchhammers studie af Nuuk anskuet som kontrast til resten af - det såkaldt rigtige; det autentiske - Grønland.

Men artiklerne begrænser sig ikke til at belyse perioden mellem 1953 til året 1979, hvor Grønland får hjemmestyre. De inddrager også det grønlandske ønske om selvstændighed, forstået som løsrivelse fra det danske Rigsfællesskab i deres analyser og bygger dermed bro over flere epoker i grønlandsk historie. Det fremgår særligt tydeligt i Kirsten Bransholm og Najaraaq Paniulas artikel om kvindeorganisationers rolle i den politiske udviklingsproces i Grønland. Den historiske optik på et aspekt af Grønland - nemlig kvindernes plads og funktion i samfundet - udgør en meget interessant fremstilling af, hvordan forskellige samfundsgrupper finder sig til rette og får plads i et samfund i transition.

Artiklerne af Annemette Nyborg Lauritsen, af Bo Wagner Sørensen og Søren Forchhammer og af Kirsten Bransholm og Najaraaq Paniula analyserer centrale problemstillinger, som har været genstand for megen dansk sociologisk forskning i identiteter og urbanisering - men ikke i forhold til Grønland. 
Her har det i høj grad tilfaldet eskimologer at beskrive spændingsfeltet mellem oprindelig inuit-identitet og moderne grønlandsk identitet. Danske eskimologer har bidraget med vigtig forskning på dette område, men som sociolog kan man savne et sociologisk blik på samme problemstilling. Tilsvarende kalder grønlændernes ønske om at udvikle en større grad af selvstændighed i forhold til Danmark og Rigsfællesskabet på sociologisk opmærksomhed på nationsdannelsesprocesser og udviklingen af national identitet på Grønland.

Det er ikke muligt at identificere et enkelt nedslagspunkt for, hvornår den grønlandske selvstændighedsbevægelse tog form. Derimod er det muligt at pege på en række faktorer, der spillede en betydelig rolle i mobiliseringen af den. Her indgår de tvangsflytninger, som Grønlands historie - både som koloni og som dansk amt - rummer eksempler på, med stor vægt. Særlig Thule-sagen fra 1953 med tvangsflytningen af 27 familier (116 enkeltpersoner) med 3 ugers varsel væk fra det område, som var tiltænkt udvidelsen af den amerikanske base, til byen Qaanaaq, er af stor betydning. Det samme gør sig gældende for tvangsflytningen fra Qullissat, hvor man i perioden 1969 til 1972 tvangsflyttede 1100 mennesker fra den store kulmineby til andre dele af Grønland som konsekvens af, at byens rolle som kulmineby var aftagende. Disse sager, som i manges øjne havde karakter af overgreb på et oprindeligt folk udført af en hensynsløs - i Qullissats tilfælde tidligere - kolonimagt af en slags, nævnes ofte som den gnist, der antændte den grønlandske selvstændighedstrang. Disse sager udgør også en substantiel del af Forsoningskommissionens opdrag, hvis man skal tage Aleqa Hammonds ord til Martin Breum i den Sorte Diamant i september 2014 for pålydende. Grønlændernes ønske om selvstændighed blev imødekommet med Loven om Hjemmestyre i 1979, som gav landet en vis grad af autonomi.

\section{Fra hjemmestyre 1979 til selvstyre 2009}

Perioden med hjemmestyre var kendetegnet ved opførelsen af en række betydelige grønlandske nationale institutioner. Grønlands Universitet, Ilisimartusarfik blev grundlagt i 1987 og havde karakter af både et uddannelsespolitisk tiltag og en national manifestation. 1980erne så også overdragelsen af grønlandsk materiale fra Nationalmuseet i København til Nationalmuseet i Nuuk. Denne overdragelse er siden hen gået over i historien som et skoleeksempel på, hvordan sådan en overdragelse bør finde sted - i skarp kontrast til overdragelsen af de islandske håndsskrifter, som gav anledning til en lang række konflikter mellem Island og Danmark i anden halvdel af det 20. århundrede. Overordnet set er perioden med grønlandsk hjemmestyre karakteriseret ved en række forskellige tiltag, som havde til mål at styrke det grønlandske islæt i Grønland og nedtone det danske. Det ses tydeligt også i skolesystemet, hvor grønlandsk i vid udstrækning erstattede dansk som undervisningssprog i folkeskolen, hvorimod dansk vedblev at være undervisningssprog i gymnasiet. 
I 2009 erstattede Loven om Selvstyre Loven om Hjemmestyre. Også i Selvstyreloven spiller sprog en afgørende rolle. Med loven om selvstyre blev grønlandsk det eneste officielle sprog på Grønland i modsætning til tidligere, hvor grønlandsk og dansk var sidestillede. Grønlandsk betyder vestgrønlandsk, som er det grønlandske nationalsprog i kontrast til østgrønlandsk og det grønlandsk, der tales i Thule-området, som har status af dialekter, desuagtet de to dialekter er så forskellige fra vestgrønlandsk, at særligt østgrønlandsk undertiden betegnes som et selvstændigt sprog.

Dette understreger, at sprogpolitik i Grønland er et yderst prekært område både politisk, kulturelt og socialt. Det knytter sig tæt sammen med diskussionen om national identitet, som har fundet sted i landet i efterhånden flere årtier, og dermed spørgsmålet om, hvad det vil sige at være grønlænder. Det er et spørgsmål, der involverer mange aspekter. F.eks. er det værd at notere sig, at den danske tilstedeværelse på Grønland har sat sig sine spor ikke kun i bybilledet i arkitekturen, som Bo Wagner Sørensen og Søren Forchhammer beskriver, men også i de grønlandske familier, hvor mange har et eller flere danske familiemedlemmer. Det sætter sit spor i sproget. Grønland anno 2015 er kendetegnet ved at være et flersproget samfund: Både grønlandsk og dansk er centrale sprog. Det spiller en afgørende rolle i forhold til uddannelse som nævnt ovenfor og dermed for de muligheder for social mobilitet, der er iboende i uddannelsessystemet. Det spiller også en stor rolle i forhold til forsøget på at blive klogere på, hvad det vil sige at være grønlænder - et spørgsmål som kalder på sociologiske bidrag. Dette nummer kan kun bidrage med nogle anslag.

Selvstyreloven gav Grønland en større grad af autonomi på en lang række områder. Samtidig åbnede loven op for, at Grønland med tiden kan vælge at hjemtage flere politikområder. På den baggrund valgte landet umiddelbart efter Selvstyrelovens ikrafttræden at hjemtage bl.a. det vigtige råstofområde, mens områder som udenrigs- og sikkerhedspolitik fortsat er et dansk anliggende. Netop denne konstellation, hvor nogle områder hører under grønlandsk lovgivning og andre under dansk, er ikke uden problemer. Det blev meget tydeligt, da det grønlandske parlament, Inatsisartut, valgte at opgive nul-tolerancen overfor brydning af uran i oktober 2013. Dermed åbnede den grønlandske regering op for, at Grønland med tiden kan blive en uran-eksporterende nation - en beslutning, som både berører råstofs- og sikkerhedspolitik. Dermed falder beslutningen indenfor både grønlandsk og dansk lovgivning, som i dette tilfælde, som i så mange andre, ikke nødvendigvis har samme interesser for øje.

Et andet beslægtet element $i$ Loven om Selvstyre er beslutningen om at fryse det danske årlige bloktilskud til Grønland på 2009-niveau, hvilket vil sige ca. 3,5 milliarder kroner. Selvstyreloven redegør for, hvordan bloktilskuddet skal nedtrappes, skulle indtægterne fra olie og mineralforekomster i Grønland strømme ind i den grønlandske landskasse. Behovet for at tage højde 
for en eventuel nedtrapning af bloktilskuddet i Loven om Selvstyre skal ses i lyset af den optimisme, der knyttede sig til Grønlands undergrund og i særdeleshed udsigterne til store oliefund, som herskede i perioden, da Selvstyreloven blev forhandlet og nedfældet.

Den optimisme, som dengang var udtalt, er sidenhen blevet afløst af en mere nøgtern stillingtagen til Grønland som mine-nation. Der er stadig gode muligheder, men perspektiverne er usikre og afhænger af faktorer, som Grønland ikke har nogen indflydelse på f.eks. internationale råstofpriser. Det kan med andre ord tage flere årtier før Grønland får omlagt sin økonomi fra at bygge på fiskeri som den vigtigste og altdominerende kilde til eksport til at koncentrere sig om minedrift. Dermed er udsigterne til økonomisk uafhængighed, betragtet som en forudsætning for politisk selvstændighed, også mindre entydigt positive. Også turisme er et spinkelt område for Grønland at bygge for meget på. Grønlands økosystem er meget skrøbeligt, og Grønlands geografi gør det svært at opbygge et ordentligt system for håndtering af spildevand og affald. Beregninger har således vist, at landet ikke kan bære den mængde turister, der skal til for at sikre landet gode indtægter fra den kilde, selvom den umiddelbart kan forekomme indlysende.

Men håbet om, at Grønland en dag kan blive en selvstændig nation, er lysegrønt, og det har en stor betydning for den enkelte grønlænder. Loven om Selvstyre foreskriver, at beslutningen om eventuel selvstændighed skal tages ved en folkeafstemning blandt den grønlandske befolkning. Grønland har dermed ret til at erklære sig selvstændigt, skulle dets befolkning ønske det.

Selvstændighed vil medføre, at bloktilskuddet, som den grønlandske økonomi i høj grad beror på, bortfalder. På den baggrund italesættes spørgsmålet om selvstændighed ofte som et valg mellem selvstændighed og opretholdelse af den nuværende levestandard. Denne problemstilling understreges af, at det grønlandske samfund har alvorlige økonomiske problemer og har svært ved at opretholde det eksisterende niveau for eksempel for sociale ydelser og services, som er en integreret del af den grønlandske velfærdsstat. Dette omtales også i Grønland som "dødens gab", da en grafisk fremskrivning af stigningen $\mathrm{i}$ udgifter og faldet $\mathrm{i}$ indtægter viser det, der med lidt morbid humor kan ligne et åbenstående hajgab. Dette har ikke mindst politisk givet anledning til overvejelser om nødvendigheden af at reformere den grønlandske velfærdsstat. Det vil blandt meget andet føre til en reduktion i de midler, der kan afsættes til tiltag og initiativer, som ofte anses for nødvendige for at afhjælpe de sociale problemer, som Grønland kæmper med, og som Steven Arnfjord og John Andersen behandler i artiklen om socialt arbejde og aktionsforskning på Grønland. Grønland har en lang række sociale udfordringer, ikke mindst hvad angår misbrug af børn, alkohol og hash. Dette er dokumenteret af Else Christensen for nogle år siden, der via en ofte refereret og meget anvendt surveyundersøgelse viste, at flertallet af de grønlandske børn har det godt, men at ca. en tredjedel lever i familier præget af alkohol, misbrug og 
fattigdom. Netop den store rolle, afhængighed spiller i det grønlandske samfund, afspejles i Christina Viskums artikel om spilafhængighed på Grønland. Omvendt kan man sige, at vælger man at undlade at reformere den grønlandske velfærdsstat, vil resultatet også være en reduktion i den offentlige indsats over for de socialt udsatte i Grønland. De økonomiske midler er simpelthen ikke til stede til at opretholde det nuværende niveau.

\section{Bidragene}

Som forordet vil ane, er Grønland et mangefacetteret samfund, der har undergået og undergår mange forandringer. Dette kan de få bidrag, der er plads til i tidsskriftet, på ingen måde rumme. De kan kun godtgøre, hvor spændende Grønland er også ud fra et sociologisk aspekt. Derved får de 5 artikler deres berettigelse og relevans. De belyser Grønland i dag ved både at diskutere landet generelt og gå ned i enkeltstående problemstillinger, som er eksempler på mere generelle tendenser. Det gør de ud fra et sociologisk perspektiv, som hidtil har været stort set fraværende i forskningen i Grønland. Artiklerne kan som sagt kun være eksempler på de mange områder, hvor man kunne ønske en øget sociologisk viden om og forskning $i$ en befolkning i voldsom forandring.

Vi lægger ud med Bo Wagner Sørensen og Søren Forchhammers artikel "Byen og bygden", som er en introduktion til nutidens Grønland med dens beskrivelse af skellet mellem Nuuk og resten af Grønland. Her lægger forfatterne vægt på, at Nuuk både anses for at være fremmed for Grønland, men at byen samtidig betragtes som en sand metropol - et pejlemærke for den moderne grønlandske nation, som er ved at tage form. Efter denne introduktion til Grønland og landets hovedstad bevæger vi os ind i nogle af de problemstillinger, som karakteriserer landet. Først overordnet ved at se på kriminalitet på Grønland og debatten om Grønland som straffende/ikke-straffende. Det gør vi med artiklen af Annemette Nyborg Lauritsen "Den store grønlandske indespærring". Her problematiserer forfatteren forestillingen om, at Grønland ikke straffer og konkluderer, at dette er en sandhed med modifikationer - en konstatering som får fornyet relevans i lyset af det forhold, at Grønlands første lukkede fængsel for øjeblikket er under opførsel. Det følges af en artikel skrevet af Christina Viskum Lytken Larsen, som analyserer en problemstilling, der er meget dominerende på Grønland, nemlig afhængighed. Dette analyseres med særligt fokus på afhængighed af pengespil. Det fører os over i socialarbejdernes indsats og diskussionen om empowerment af denne gruppe, som Steven Arnfjord og John Andersen tager under kærlig behandling i deres artikel "Socialt arbejde og aktionsforskning i Grønland". Artiklens fokus på denne gruppe af offentligt ansatte og deres vilkår og arbejdsforhold sætter spot på kvindernes rolle i samfundet, da langt de fleste socialarbejdere er kvinder. Forfatternes engagement $\mathrm{i}$ denne gruppe ikke mindst $\mathrm{i}$ forhold til empowerment leder os over i den afsluttende artikel skrevet af Kirsten Bransholm Peder- 
sen og Najaraaq Paniula om kvindeorganisationer - før og nu. Dermed sluttes ringen, og vi bringes tilbage til det generelle niveau med artiklen om kvindernes rolle i Grønlands politiske udviklingsproces i et historisk perspektiv.

Nummeret er illustreret af fotos fra en fotokonkurrence i Grønland, hvor vinderne blev afsløret i Nuuk i marts 2014. Konkurrencen blev kaldt "Isiøjeeye". Projektet var målrettet personer med bopæl i Grønland, der blev opfordret til at indsende deres egne digitale fotos. I alt 40 fotos blev udvalgt blandt de fremsendte, og de kan alle ses på hjemmesiden http://isi.nebula. $\mathrm{gl} / \mathrm{da} /$. Nogle af billederne er kunstneriske, andre viser mere råt for usødet hverdagen. Vi har været glade for at kunne bringe eksempler fra de mange indsendte fotos, fordi vi opfatter projektet som en fin forlængelse af nummerets præsentation af en række sociologiske problemstillinger i Grønland. Med projektets egne ord inddrager fotokonkurrencen befolkningen, viser befolkningens personlige fortolkninger af deres store land og viser kultur og natur i byer og bygder. Vi har desværre ikke kunnet medtage alle fotos, der ellers hver især viser aspekter af landet som underbygger artiklerne. Ingen nævnt ingen glemt. Vi vil gerne opfordre til, at man selv kigger videre for at se de mange fotos, vi ikke fik plads til.

Benedikte Brincker og Esther Nørregård-Nielsen 